УДК 378.07:005.52

Тоцька Олеся,

кандидат економічних наук, доцент,

Східноєвропейський національний університет імені Лесі Українки,

кафедра менеджменту,

м. Луцьк; ORCID ID 0000-0003-4748-2134

e-mail: Totska.Olesia@eenu.edu.ua

https://doi.org/10.29038/2411-4014-2020-03-58-66

\title{
СИСТЕМА МЕТОДІВ АНАЛІЗУ ТА ПРОГНОЗУВАННЯ КЛЮЧОВИХ СФЕР ДІЯЛЬНОСТІ ВИЩОЇ ОСВІТИ УКРАЇНИ
}

У статті розроблено методологічний алгоритм комплексної діагностики розвитку й ефективності управління вищою освітою України на макро- та мікрорівні, який складається з чотирьох послідовних етапів: аналіз розвитку вищої освіти в Україні; аналіз ефективності управління розвитком вищої освіти в Україні; прогнозування розвитку вищої освіти в Україні; розробка стратегічних напрямів розвитку вищої освіти в Україні. Охарактеризовано використовувані для аналізу освітньої, наукової, фінансово-інвестиційної сфер діяльності вищої освіти методи: SWOT-аналіз, компонентний аналіз, критичного шляху, дерево рішень, АBCаналіз, екстраполяція трендів, кластерний аналіз, побудова інтегрального показника, нечітких множин, імовірнісно-автоматне моделювання.

Ключові слова: вища освіта України, діагностика, розвиток, ефективність управління, методи аналізу та прогнозування.

Тоцкая Олеся, кандидат экономических наук, доцент, Восточноевропейский национальный университет имени Леси Украинки, кафедра менеджмента, г. Луцк

\section{СИСТЕМА МЕТОДОВ АНАЛИЗА И ПРОГНОЗИРОВАНИЯ КЛЮЧЕВЫХ СФЕР ДЕЯТЕЛЬНОСТИ ВЫСШЕГО ОБРАЗОВАНИЯ УКРАИНЫ}

В статье разработан методологический алгоритм комплексной диагностики развития и эффективности управления высшим образованием Украины на макро- и микроуровне, который состоит из четырех последовательных этапов: анализ развития высшего образования в Украине; анализ эффективности управления развитием высшего образования в Украине; прогнозирования развития высшего образования в Украине; разработка стратегических направлений развития высшего образования в Украине. Охарактеризованы используемые для анализа образовательной, научной, финансово-инвестиционной сфер деятельности высшего образования методы: SWOT-анализ, компонентный анализ, критического пути, дерево решений, АВС-анализ, экстраполяция трендов, кластерный анализ, построение интегрального показателя, нечетких множеств, вероятностно-автоматное моделирования.

Ключевые слова: высшее образование Украины, диагностика, развитие, эффективность управления, методы анализа и прогнозирования.

Totska Olesia,

PhD in Economics, Associate Professor, Lesya Ukrainka Eastern European National University, Department of Management, Lutsk

\section{SYSTEM OF METHODS OF ANALYSIS AND FORECASTING OF KEY AREAS OF HIGHER EDUCATION ACTIVITY OF UKRAINE}


Introduction. Education in general and higher education in particular play an important role in shaping the national knowledge economy. For effective management of the development of higher education in general and higher education institutions in particular, it is advisable to diagnose in what condition they are today and predict their condition in the future. The purpose of the article is to form a system of methods of analysis and forecasting of key areas of higher education in Ukraine. Results. The first stage of the methodology of complex diagnostics of development and efficiency of management of higher education of Ukraine "Analysis of development of higher education in Ukraine» provides the decision of three consecutive tasks: the analysis of system of higher education in Ukraine; analysis of scientific and innovative development of Ukraine in the regional context; analysis of financial and investment support for the development of higher education. The second stage "Analysis of the effectiveness of management of higher education in Ukraine» consists of three consecutive tasks: analysis of the effectiveness of management of educational, scientific and financial components of higher education. The third stage «Forecasting the development of higher education in Ukraine» involves solving the following tasks: modeling the development of educational and scientific components of higher education, financial and investment support for its development. The fourth stage «Development of strategic directions for the development of higher education in Ukraine» consists of three consecutive tasks: educational and social, scientific and innovative, financial and investment areas for the development of higher education. Conclusions. It is proposed to conduct a comprehensive diagnosis of the development and effectiveness of higher education management in Ukraine at the macro and micro levels, analyzing its key areas of activity (educational, scientific, financial and investment) using the following methods: SWOT-analysis, component analysis, critical path, decision tree, ABC-analysis, trend extrapolation, cluster analysis, construction of an integrated exponent, fuzzy sets, probabilistic-automatic modeling.

Keywords: higher education of Ukraine, diagnostics, development, management efficiency, methods of analysis and forecasting.

Постановка проблеми та іï значення. Освіті загалом і вищій освіті зокрема відводиться важлива роль у формуванні національної економіки знань. Організація економічного співробітництва та розвитку (ОЕСР) у документі «Економіка на основі знань» зазначає, що іiі політика в галузі науки, техніки та промисловості повинна бути сформульована таким чином, щоб максимально підвищити ефективність і добробут у «економіках, що базуються на знаннях», тобто тих, які безпосередньо грунтуються на виробництві, розподілі й використанні знань та інформації. Це відображається в тенденціях економік ОЕСР до зростання у високотехнологічних інвестиціях і галузях промисловості, більш висококваліфікованій робочій силі та пов'язаним із цим підвищенням продуктивності. Ключовими є інвестиції в дослідження й розробки, освіту та навчання, а також нові структури управлінської роботи [1, с. 7]. Для ефективного управління розвитком вищої освіти загалом і закладами вищої освіти (ЗВО) зокрема доцільно продіагностувати за допомогою системи методів, в якому стані вони знаходиться на сьогодні та спрогнозувати їхній стан у майбутньому.

Аналіз останніх досліджень і публікацій. Вітчизняні наковці в цьому контексті пропонують розглядати велику кількість показників i використовувати різноманітні методики. Зокрема, Б. І. Холод і О.В. Дашевська зауважують, що процес стратегічного планування діяльності 3 ВО включає в себе декілька обов'язкових етапів: проведення ситуаційного аналізу; визначення стратегічних цілей, бачення та місії; вибір моделі й методів реалізації стратегії; розробка організаційної структури для реалізації обраної стратегічної моделі. Ними виділені такі групи показників комплексної діагностики 3ВО: система управління; організаційна структура; фінансовоекономічна група; маркетингова система; кадрова система [2].

Л. В. Жук запропонувала проведення симптоматичної діагностики системи наукової та науковотехнічної діяльності ЗВО за такими етапами: вибір об'єкта діагностики; формулювання мети та завдань діагностики; визначення формату дослідження й джерел отримання інформації; формування інформаційної бази показників; визначення та обгрунтування системи репрезентативних індикаторів; визначення й обгрунтування нормативно-критеріальних значень для обраних індикаторів; виконання аналітичних процедур (визначення симптомів); визначення причин, які зумовили виникнення проблем або призвели до отримання позитивного результату; систематизування отриманої інформації, формування висновків про стан системи наукової та науково-технічної діяльності (встановлення діагнозу); формулювання варіантів рішень і можливостей розв'язання ключових проблем [3]. 
Мета і завдання статті. Метою статті є сформувати систему методів аналізу та прогнозування ключових сфер діяльності вищої освіти України. Для іiі реалізації поставлено й виконано такі завдання:

- розробити методологічний алгоритм комплексної діагностики розвитку й ефективності управління вищою освітою України;

- охарактеризувати використовувані для діагностики методи;

- визначити перспективи подальших досліджень у цьому напрямі.

Викладення основного матеріалу та обгрунтування отриманих результатів дослідження. Ми пропонуємо проводити комплексну діагностику розвитку й ефективності управління вищою освітою України на макро- та мікрорівні, аналізуючи при цьому іiі ключові сфери діяльності (освітню, наукову, фінансово-інвестиційну). Запропонований методологічний алгоритм включає чотири послідовні етапи. Його відображено на рис. 1.

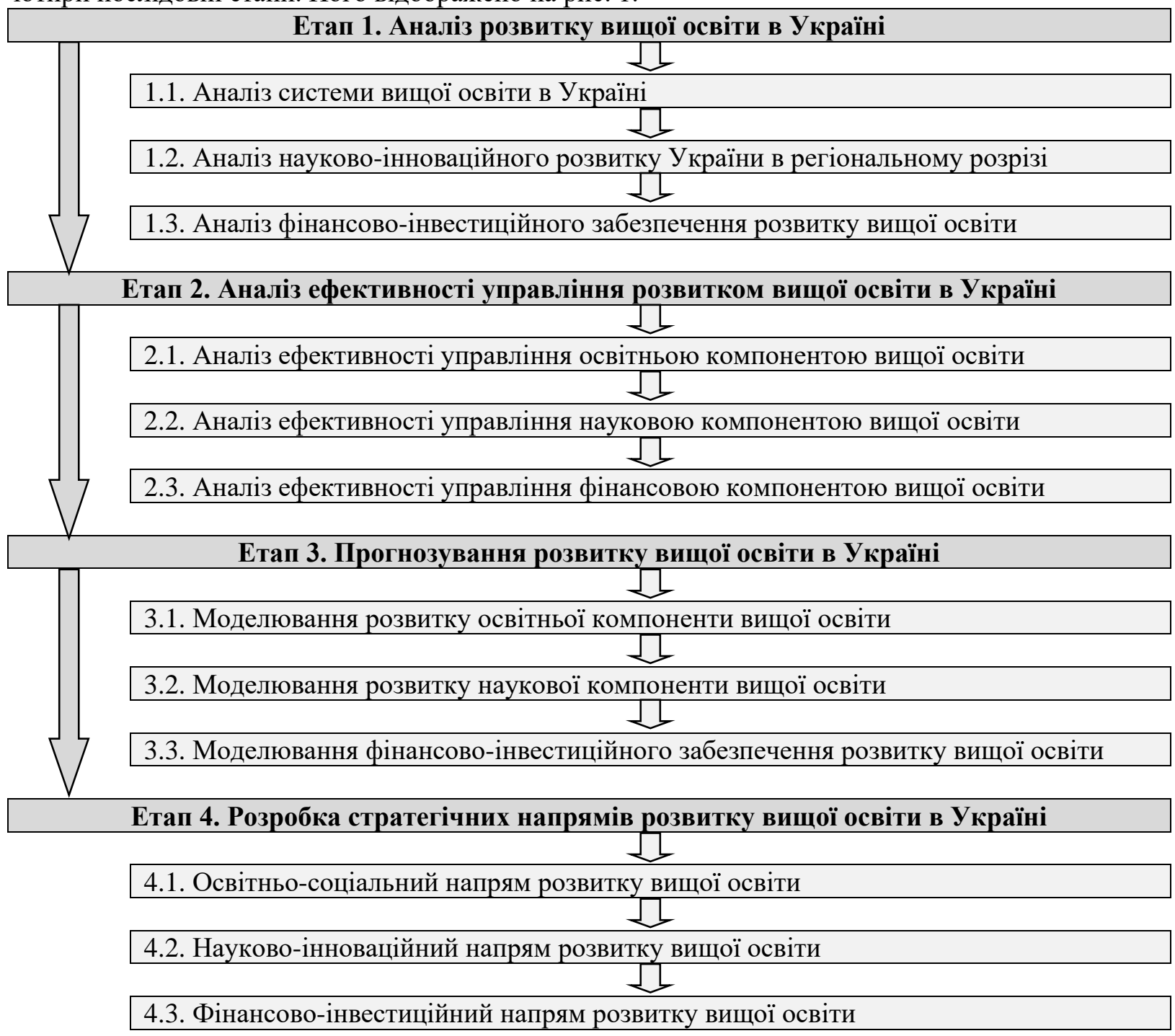

Рис. 1. Методологічний алгоритм комплексної діагностики розвитку й ефективності управління вищою освітою України

Джкерело: Власна розробка автора.

На першому етапі методології проводиться:

- SWOT-аналіз системи вищої освіти на основі 30 показників (частка осіб, прийнятих на навчання до університетів, академій, інститутів, серед потенційних абітурієнтів; кількість коледжів, технікумів, училищ/університетів, академій, інститутів; кількість осіб у коледжах, технікумах, училищах/університетах, академіях, інститутах; кількість осіб, прийнятих на навчання/випущених із 
коледжів, технікумів, училищ/університетів, академій, інститутів; вартість основних засобів освітніх закладів; чисельність викладацького складу коледжів, технікумів, училищ/університетів, академій, інститутів; кількість аспірантів/докторантів; платні послуги 3ВО; капітальні інвестиції в освіту; держбюджетне фінансування 3ВО; академічна мобільність; взаємне визнання країнами документів про освіту, наукові ступені та вчені звання; безробіття випускників; кількість абонентів мережі «Інтернет»; кількість випущених учнів, які одержали атестат про здобуття повної загальної середньої освіти; середньомісячна зарплата освітян; державні премії, стипендії та гранти; навчання студентів за рахунок коштів фізичних і юридичних осіб; життєвий рівень населення; індекси споживчих цін; законодавча база; навчання іноземців; конкуренція з боку закордонних 3ВО);

- компонентний аналіз розвитку вищої освіти на основі п’яти показників (кількість ЗВО; кількість студентів у 3ВО; кількість студентів, прийнятих на навчання/випущених із ЗВО; кількість студентів-іноземців у ЗВО);

- кластерний аналіз регіонів України за 12 показниками науково-інноваційної діяльності (кількість установ, які здійснюють підготовку аспірантів/докторантів; кількість аспірантів/докторантів; організації, які здійснювали наукові дослідження і розробки (НДіР); кількість працівників, задіяних у виконанні НДіР; валові витрати на виконання НДіР; кількість промислових підприємств, які займалися інноваційною діяльністю; питома вага промислових підприємств, які займалися інноваційною діяльністю; кількість упроваджених нових технологічних процесів; кількість найменувань упроваджених інноваційних видів продукції; загальний обсяг фінансування інноваційної діяльності);

- аналіз динаміки фінансово-інвестиційних показників (загальні та державні витрати на освіту як \% від ВВП; показники сателітного (допоміжного) рахунку освіти в Україні; доходи, видатки, граничний обсяг дефіциту держбюджету; видатки та частки видатків держбюджету на МОН України (в розрізі видатків); капітальні інвестиції в освіту України);

- аналіз інвестування в економіку України на основі інтегрального показника (капітальні інвестиції за видами економічної діяльності (ВЕД) (у т. ч. освіти); рейтинги ВЕД (у т. ч. освіти) за рівнем капітальних інвестицій).

На другому етапі методології відбувається:

- управління проєктом проведення вступної кампанії 3ВО (трудові, матеріальні та фінансові ресурси проєкту) за допомогою методу критичного шляху;

- АВС-аналіз ефективності проведення вступної кампанії ЗВО та Всеукраїнської студентської олімпіади (розмір плати за рік навчання у ЗВО; кількість зарахованих на 1-й курс ЗВО та їх сукупний річний розмір плати; частка та накопичена частка спеціальності в загальній сумі; група АВС спеціальностей/факультетів; ЗВО; кількість переможців Всеукраїнської студентської олімпіади; частка та накопичена частка ЗВО в загальній кількості; група АВС ЗВО);

- управління проєктом проведення Всеукраїнського конкурсу студентських наукових робіт (трудові, матеріальні та фінансові ресурси проєкту);

- аналіз динаміки показників ефективності управління науковою компонентою вищої освіти (кількість осіб, які закінчили аспірантуру/докторантуру із захистом дисертації);

- управління проєктами підготовки доктора філософії/доктора наук (трудові та фінансові ресурси проєктів);

- побудова дерева рішень для атестації аспірантів/докторантів (атестація аспірантів/докторантів залежно від рівнів роботи над дисертацією та публікаціями й рівня опрацювання літературних джерел);

- побудова дерева рішень для визначення оптимальної ціни підготовки фахівців у ЗВО (визначення оптимальної ціни підготовки фахівців у ЗВО залежно від кількості конкурентів; різниці в цінах за навчання; наявності серед конкурентів національного ЗВО).

На третьому етапі методології проводиться побудова прогнозних екстраполяційних моделей випускників закладів повної загальної середньої освіти/коледжів, технікумів, училищ; академічної мобільності; вступників університетів, академій, інститутів; наукових досліджень і розробок; діяльності аспірантури/докторантури; держбюджетного стимулювання наукової діяльності у ЗВО; держбюджетного фінансування МОН України, вітчизняних ЗВО та заробітної плати (3/п) освітян; 
імовірнісно-автоматне моделювання стану казначейських рахунків 3ВО; прогнозування капітальних інвестицій в освіту України за допомогою методу нечітких множин.

Четвертий етап методології складається 3 трьох послідовних завдань: освітньо-соціальний, науково-інноваційний і фінансово-інвестиційний напрями розвитку вищої освіти.

Зауважимо, що методологія - це сукупність прийомів дослідження, що застосовуються в науці [4]. Методи та завдання, які застосовано в розробленій методології, подано на рис. 2. Слід зазначити, що SWOT-аналіз дозволяе охопити всі три найважливіші сфери діяльності - освітню, наукову, фінансово-інвестиційну - в комплексі, тому на рис. 2 його не подано.

Охарактеризуємо використовувані для діагностики методи детальніше.

SWOT-аналіз - один із найпопулярніших методів стратегічного управління. Його назва утворилась як абревіатура чотирьох англійський слів: «strengths» (сильні сторони), «weaknesses» (слабкі сторони), «оpportunities» (можливості), «threats» (загрози). За його допомогою можна вивчати в нерозривному зв'язку зовнішнє та внутрішнє середовища об'єкта дослідження.

Основне призначення методу головних компонент - виявити приховані першопричини, які пояснюють кореляції між ознаками та змістовно інтерпретуються. Його використання грунтується на припущенні, що ознаки $x_{i} \in$ лише індикаторами певних властивостей явища, які існують, але безпосередньо не вимірюються. Якщо таких першопричин декілька, в просторі ознак $X$ виокремлюються групи висококорельованих ознак. Першопричина кореляції ознак $j$-ї групи називається компонентою $G_{j}$. Ознаки, що належать до різних груп, - некорельовані, а отже, i компоненти $G_{j}$ - незалежні (ортогональні).

Суть методу полягає в переході від численної множини $x_{i}$ до мінімальної кількості максимально інформативних компонент $G_{j}$. У моделі головних компонент зв’язок між первинними ознаками та компонентами описується як лінійна комбінація

$$
z_{i}=\sum_{1}^{m} a_{i j} G_{j}
$$

де $z_{i}$ - стандартизовані значення $i$-ї ознаки з одиничними дисперсіями (сумарна дисперсія дорівнює кількості однак $m$ );

$a_{i j}$ - факторне навантаження $j$-ї компоненти на $i$-у ознаку, яке характеризує щільність зв'язку між $i$-ю ознакою та $j$-ю компонентою (змінюється в межах від 0 до \pm 1 ) [5, с. 149-150].

Метод критичного шляху відноситься до основних методів сіткового планування, яке полягає у створенні логічних діаграм послідовності виконання проєктних робіт - сіткових графіків - i визначенні тривалості цих робіт й проєкту в цілому з метою подальшого контролю [6, с. 148-149]. Відповідно до нього, для кожного виду робіт вказуються час і ресурси, необхідні для їхнього виконання, а також послідовність виконання окремих видів робіт. Потім будується граф (сітковий графік), що відображає черговість робіт і терміни їхнього виконання. Далі на цьому графі шукається критичний шлях, тобто шлях, що вимагає максимальних витрат часу. Ключовою перевагою методу критичного шляху $є$ можливість маніпулювання термінами виконання робіт, що не лежать на критичному шляху [6, с. 150-151].

$A B C$-аналіз - це аналітичний метод, за допомогою якого визначають ступінь розподілу конкретної характеристики між окремими елементами якої-небудь множини [7, с. 144]. Він грунтується на так званому законі Парето (20/80, «великого пальця»), згідно якого п'ята частина (20\%) від усієї кількості об'єктів дає зазвичай близько $80 \%$ результатів, а внесок решти $80 \%$ становить лише 20 \%. Суть принципу Парето полягає в тому, що в процесі досягнення будь-якої цілі нераціонально приділяти рівну увагу об'єктам, які мають незначну віддачу й об'єктам, які є визначальними [8, с. 108-109]. Застосування АВС-аналізу дозволяє здійснити глибший, порівняно із принципом Парето, поділ: розбити початкову множину об'єктів на три підмножини, залежно від їх питомої ваги в загальному значенні певного показника (А - близько $80 \%, \mathrm{~B}$ - близько $15 \%$, С близько $5 \%)$. 


\begin{tabular}{|c|c|c|}
\hline Методи діагностики & $\begin{array}{c}\text { Сфери } \\
\text { діяльності 3ВО }\end{array}$ & Завдання для вирішення \\
\hline & Освітня & \\
\hline Головних компонент & & 1. Компонентний аналіз розвитку вищої освіти. \\
\hline Критичного шляху & & $\begin{array}{lll}\text { 2. Планування } \\
\text { кампанії ЗВО. }\end{array}$ \\
\hline АВС-аналіз & & 3. Діагностика вступної кампанії 3ВО. \\
\hline Критичного шляху & & $\begin{array}{lcr}\text { 4. Управління } & \text { проєктом } & \text { проведення } \\
\text { Всеукраїнського конкурсу студентських наукових } \\
\text { poбіт. }\end{array}$ \\
\hline АВС-аналіз & & $\begin{array}{l}\text { 5. Діагностика проведення } \\
\text { студентської олімпіади. }\end{array}$ \\
\hline Екстраполяції трендів & & $\begin{array}{l}\text { 6. Прогнозування розвитку освітньої компоненти } \\
\text { вищої освіти. }\end{array}$ \\
\hline Кластерний аналіз & Наукова & $\begin{array}{l}\text { 1. Групування регіонів України за показниками } \\
\text { науково-інноваційної діяльності. }\end{array}$ \\
\hline Критичного шляху & & $\begin{array}{l}\text { 2. Управління проєктами підготовки доктора } \\
\text { філософії/доктора наук. }\end{array}$ \\
\hline Дерево рішень & & 3. Атестація аспірантів/докторантів. \\
\hline Ецстпапопячії тренпір & & $\begin{array}{lcc}\text { 4. Побудова прогнозних } & \text { моделей } & \text { розвитку } \\
\text { наукової компоненти вищої освіти. } & \\
\end{array}$ \\
\hline Екстраполяц11 тренд1в & & $\begin{array}{l}\text { 5. Побудова прогнозних моделей держбюджет- } \\
\text { ного стимулювання наукової діяльності в ЗВО. }\end{array}$ \\
\hline & $\begin{array}{l}\text { Фінансово- } \\
\text { інвестиційна }\end{array}$ & \\
\hline Дерево рішень & & $\begin{array}{l}\text { 1. Визначення оптимальної вартості підготовки } \\
\text { фахівців у 3ВО з урахуванням цін конкурентів. }\end{array}$ \\
\hline $\begin{array}{c}\text { Побудова інтеграль- } \\
\text { ного показника }\end{array}$ & & $\begin{array}{l}\text { 2. Побудова інтегрального показника інвестування } \\
\text { в економіку України. }\end{array}$ \\
\hline Екстраполяції трендів & & $\begin{array}{l}\text { 3. Побудова прогнозних моделей держбюджет- } \\
\text { ного фінансування ЗВО України та з/п освітян. }\end{array}$ \\
\hline $\begin{array}{c}\text { Імовірнісно-авто- } \\
\text { матне моделювання }\end{array}$ & & $\begin{array}{l}\text { 4. Моделювання стану казначейських рахунків } \\
\text { ЗВО. }\end{array}$ \\
\hline Нечітких множин & & 5. Прогнозування інвестицій в освіту України. \\
\hline
\end{tabular}

Рис. 2. Методи та завдання комплексної діагностики розвитку й ефективності управління вищою освітою Украӥни

Джерело: Власна розробка автора. 
Метод екстраполячії трендів. Екстраполяція - поширення минулих і сучасних закономірностей, зв'язків і співвідношень на майбутнє. Методи екстраполяції є найпоширенішими методами короткострокового прогнозування [9, с. 74]. У свою чергу, тренд відображає тенденцію зміни явища (процесу, об'єкта) в часі. Його рівняння має вигляд:

$$
y=f(t)+\xi_{t},
$$

де $f(t)$ - детермінована невипадкова компонента процесу (явища);

$\xi_{t}$ - стохастична (випадкова) компонента процесу (явища) [10, с. 22].

Кластерний аналіз (від англ. cluster - гроно, згусток) є сукупністю методів класифікації багатовимірних спостережень, основна мета якої полягає в розподілі вхідних даних на однорідні групи так, щоб об’єкти всередині групи були схожими між собою згідно з деяким критерієм, а об'єкти з різних груп відрізнялися один від одного. Причому класифікація об'єктів проводиться одночасно за декількома ознаками на основі введення певної міри сумарної близькості за всіма ознаками класифікації [11, с. 129]. Кластерний аналіз дає змогу аналізувати достатньо великий обсяг інформації і різко скорочувати великі масиви соціально-економічної інформації, робити їх компактними й наочними [12, с. 50].

Дерево рішень - це метод, який дає змогу з допомогою графіка з’ясувати розгалуження проблем i рішень, краще оцінити наявність альтернатив та їх кількість. На графік наносяться всі кроки, які необхідно розглянути, оцінюючи різні альтернативи. Дерево рішень підкреслює два основних моменти: використання інформації, зібраної у процесі підготовки до ухвалення рішення, i усвідомлення послідовного характеру процесу ухвалення рішення. Таким чином, дерево рішень - це схема того, до якого вибору в майбутньому приведе прийняте сьогодні рішення [13, с. 25].

Побудова інтегрального показника відбувається тоді, коли виникає потреба згортання системи показників, які описують певне явище, в один інтегральний. Тобто використання інтегрального показника зводить ситуацію полікритеріального оцінювання до монокритеріального. Його побудова відбувається в адитивній (у якій вплив окремих компонент підсумовується) чи у мультиплікативній (у якій вплив окремих складових частин множиться) формі.

Апарат імовірнісно-автоматного моделювання є:

- гнучким, оскільки дає змогу модифікувати модель при зміні в постановці задачі, конкретизації певних аспектів системи або виникненні деякого принципово різного набору даних;

- достатньо формалізованим для того, щоб будувати моделі взаємодії внутрішніх факторів системи та факторів впливу зовнішнього середовища;

- наочним i простим для розуміння, оскільки зв’язок між характеристиками системи здійснюється за допомогою арифметичних операцій $[14$, с. 36].

Будь-яка імовірнісно-автоматна модель відображається за допомогою таких п’яти характеристик:

1) вектора початкових станів - задає внутрішні стани автоматів у початковий момент часу;

2) матриці алфавітів - деталізує для кожного автомата, які значення можуть приймати його внутрішній стан, вхідні та вихідний сигнали;

3) системи функцій виходів - є сукупністю систем, за якими відбувається перерахування вихідних сигналів автоматної моделі;

4) таблиці умовних функціоналів-переходів - за ii допомогою виконується обчислення внутрішніх станів автоматів моделі в наступний $(t+1)$ момент часу на основі даних, отриманих у попередній момент часу $(t)$;

5) системи розподілу незалежних випадкових величин - у ній представлено всі випадкові величини, які впливають на зміну внутрішніх станів моделі [15, с. 130].

Метод нечітких множин. Нечіткою (під)множиною $A$ на множині $X$ вважається сукупність пар вигляду $\left(x, \mu_{A}(x)\right)$, де $x \in X$, а $\mu_{A}$ - функція $x \rightarrow[0,1]$, яка називається функцією належності нечіткої (під)множини $A$. Значення $\mu_{A}(x)$ для конкретного $x$ вважається мірою належності цього елемента нечіткій (під)множині $A$ [16, с. 490]. Причому рівень належності задається в діапазоні 
$[0,1][17$, с. 225]. Найчастіше для формування функції належності вибирають трапецієподібний і трикутний способи.

Висновки і перспективи подальших досліджень. У межах цього дослідження запропоновано проводити комплексну діагностику розвитку й ефективності управління вищою освітою України на макро- та мікрорівні, аналізуючи при цьому ії освітню, наукову, фінансово-інвестиційну сфери діяльності за допомогою системи таких методів: SWOT-аналіз, компонентний аналіз, критичного шляху, дерево рішень, АВС-аналіз, екстраполяція трендів, кластерний аналіз, побудова інтегрального показника, нечітких множин, імовірнісно-автоматне моделювання.

Перспективи подальших досліджень вбачаємо у розширенні кола методів і моделей для дослідження сфери вищої освіти України.

\section{Джерела та література}

1. The Knowledge-Based Economy. OECD/GD(96)102. Paris: Organization for Economic Co-operation and Development, 1996. 45 p. URL: http://www.oecd.org/ (дата звернення: 03.08.2020).

2. Холод Б. І., Дашевська О. В. Методика вибору та обгрунтування стратегії розвитку вищого навчального закладу. Академічний огляд. 2011. № 2(35). С. 5-11. URL: http://acadrev.duan.edu.ua/images/PDF/2011/2/1.pdf (дата звернення: 03.08.2020).

3. Жук Л. В. Формування та розвиток систем наукової і науково-технічної діяльності у закладах вищої освіти: автореф. дис. на здобуття наук. ступеня д-ра екон. наук. Львів, 2019. 41 с.

4. Методологія. Вікіпедія: вебсайт. URL: https://uk.wikipedia.org/wiki/Методологія (дата звернення: 03.08.2020).

5. Єріна А. М. Статистичне моделювання та прогнозування: навч. посіб. Київ: КНЕУ, 2001. 170 с. URL: http://www.gmdh.net/articles/theory/StatModeling.pdf (дата звернення: 03.08.2020).

6. Довгань Л. Є., Мохонько Г. А., Малик І. П. Управління проектами: навч. посіб. до вивчення дисципліни для магістрів галузі знань 07 «Управління та адміністрування» спеціальності 073 «Менеджмент» спеціалізації: «Менеджмент і бізнес-адміністрування», «Менеджмент міжнародних проектів», «Менеджмент інновацій», «Логістика». Київ: КПI ім. Ігоря Сікорського, 2017.420 c. $\quad$ URL: http://ela.kpi.ua/bitstream/123456789/19481/1/DMM_UP_2017.pdf (дата звернення: 03.08.2020).

7. Заборська Н. К., Жуковська Л. Е. Основи логістики: навч. посіб. Одеса: ОНАЗ ім. О. С. Попова, 2011. 216 c. URL: http://www.dut.edu.ua/uploads/1_201_33535647.pdf (дата звернення: 03.08.2020).

8. Дудар Т. Г., Волошин Р. В. Основи логістики: навч. посіб. URL: http://dspace.tneu.edu.ua/bitstream/316497/451/1/основи\%20логістики\%20дудар\%20волошин.pdf (дата звернення: 03.08.2020).

9. Світлична Т. І., Дріль Н. В. Конспект лекцій з дисципліни «Прогнозування» (для студентів 3 курсу денної і 4 курсу заочної форм навчання напряму підготовки 6.030504 «Економіка підприємства» 0501 «Економіка і підприємництво» спеціальності ЕП). Харків: Харк. нац. акад. міськ. госп-ва, 2010. 112 с. URL: http://eprints.kname.edu.ua/16252/1/2010_-2 печ.вар. прогнозир.лекц.январь_в новом формате. doc.pdf (дата звернення: 03.08.2020).

10. Грабовецький Б. Є. Планування та економічне прогнозування: навч. посіб. Вінниця: ВНТУ, 2013. 66 с. URL: http://hrabovecky.vk.vntu.edu.ua/file/b62a24a7998a0cfba91c11 ba7ec693df.pdf (дата звернення: 03.08.2020).

11. Єлейко В. І. Основи економетрії. Львів: Марка ЛТД, 1995. 192 с.

12. Голиков А. П. Экономико-математическое моделирование мирохозяйственных процессов: учеб. пособ. Харьков: Изд-во ХНУ, 2003. 104 с.

13. Орлів М. С. Підготовка і прийняття управлінських рішень: навч.-метод. матеріали / упоряд. Г. І. Бондаренко. Київ: http://academy.gov.ua/NMKD/library_nadu/Navch_Posybniky/52a015a3-5ad9-4fd6-8bf0-036e5711013d.pdf (дата звернення: 03.08.2020).

14. Костіна Н., Тарангул Л., Сучок С. Застосування автоматних моделей для прогнозування податкових надходжень. Економіст. 2002. № 2. С. 36-39.

15. Костіна Н. І., Сучок С. В. Оптимізація кількості комерційних банків на основі ймовірнісно-автоматної моделі. Актуальні проблеми економіки. 2005. № 2. С. 128-139.

16. Зайченко Ю. П. Исследование операций. Изд. 3-е, перераб. и доп. Киев: Вища шк., 1988. 552 с.

17. Вовк В. М. Математичні методи дослідження операцій в економіко-виробничих системах: монографія. Львів: Вид-во ЛНУ ім. І. Франка, 2007. 584 с. 


\section{References}

1. The Knowledge-Based Economy. OECD/GD(96)102. (1996). Paris: Organization for Economic Co-operation and Development. Retrieved from http://www.oecd.org/ [in English].

2. Kholod, B. I. \& Dashevska, O. V. (2011). Metodyka vyboru ta obgruntuvannia stratehii rozvytku vyshchoho navchalnoho zakladu [Methods of selection and substantiation of the development strategy of a higher educational institution]. Akademichnyi ohliad - Academic review, № 2(35), 5-11. Retrieved from http://acadrev.duan.edu.ua/images/PDF/2011/2/1.pdf [in Ukrainian].

3. Zhuk, L. V. (2019). Formuvannia ta rozvytok system naukovoi i naukovo-tekhnichnoi diialnosti u zakladakh vyshchoi osvity [Formation and development of systems of scientific and scientific and technical activity in institutions of higher education]. Lviv [in Ukrainian].

4. Metodolohiia [Methodology]. (2020, August 03). In Wikipedia. Retrieved from https://uk.wikipedia.org/wiki/Методологія [in Ukrainian].

5. Yerina, A. M. (2001). Statystychne modeliuvannia ta prohnozuvannia [Statistical modeling and forecasting]. Kyiv: KNEU. Retrieved from http://www.gmdh.net/articles/theory/StatModeling.pdf [in Ukrainian].

6. Dovhan, L. Ye., Mokhonko, H. A. \& Malyk, I. P. (2017). Upravlinnia proektamy [Project management]. Kyiv: KPI im. Ihoria Sikorskoho. Retrieved from http://ela.kpi.ua/bitstream/123456789/19481/1/DMM_UP_2017.pdf [in Ukrainian].

7. Zaborska, N. K. \& Zhukovska, L. E. (2011). Osnovy lohistyky [Fundamentals of logistics]. Odesa: ONAZ im. O. S. Popova. Retrieved from http://www.dut.edu.ua/uploads/1_201_33535647.pdf [in Ukrainian].

8. Dudar, T. H. \& Voloshyn, R. V. Osnovy lohistyky [Fundamentals of logistics]. Retrieved from http://dspace.tneu.edu.ua/bitstream/316497/451/1/основи\%20логістики\%20дудар\%20волошин.pdf [in Ukrainian].

9. Svitlychna, T. I. \& Dril, N. V. (2010). Konspekt lektsii z dystsypliny «Prohnozuvannia» [Lecture notes on the subject «Forecasting»]. Kharkiv: Khark. nats. akad. misk. hosp-va. Retrieved from http://eprints.kname.edu.ua/16252/1/2010_-2_печ.вар. прогнозир.лекц.январь_в_новом_формате._doc.pdf [in Ukrainian].

10. Hrabovetskyi, B. Ye. (2013). Planuvannia ta ekonomichne prohnozuvannia [Planning and economic forecasting]. Vinnytsia:
http://hrabovecky.vk.vntu.edu.ua/file/b62a24a7998a0cfba91c11ba7ec693df.pdf [in Ukrainian].

11. Yeleiko, V. I. (1995). Osnovy ekonometrii [Fundamentals of econometrics]. Lviv: Marka LTD [in Ukrainian].

12. Golikov, A. P. (2003). E`konomiko-matematicheskoe modelirovanie mirokhozyajstvenny`kh proczessov [Economic and mathematical modeling of world economic processes]. Khar`kov: Izd-vo KhNU [in Russian].

13. Orliv, M. S. (2013). Pidhotovka i pryiniattia upravlinskykh rishen [Preparation and decision-making] / uporiad. H. I. Bondarenko. Kyiv: NADU. $\quad$ Retrieved from http://academy.gov.ua/NMKD/library_nadu/Navch_Posybniky/52a015a3-5ad9-4fd6-8bf0-036e5711013d.pdf [in Ukrainian].

14. Kostina, N., Taranhul, L. \& Suchok, S. (2002). Zastosuvannia avtomatnykh modelei dlia prohnozuvannia podatkovykh nadkhodzhen [Application of automatic models for forecasting tax revenues]. Ekonomist - Economist, № 2, 36-39 [in Ukrainian].

15. Kostina, N. I. \& Suchok, S. V. (2005). Optymizatsiia kilkosti komertsiinykh bankiv na osnovi ymovirnisnoavtomatnoi modeli [Optimization of the number of commercial banks based on the probabilistic-automatic model]. Aktualni problemy ekonomiky - Current economic problems, № 2, 128-139 [in Ukrainian].

16. Zajchenko, Yu. P. (1988). Issledovanie operaczij [Operations research]. Kiev: Vyshcha shk. [in Russian].

17. Vovk, V. M. (2007). Matematychni metody doslidzhennia operatsii v ekonomiko-vyrobnychykh systemakh [Mathematical methods of operations research in economic and production systems]. Lviv: Vyd-vo LNU im. I. Franka [in Ukrainian].

Стаття надійшла до редакції 20.08.2020 р. 